\title{
Shifting to digital during COVID-19: are teachers empowered to give voice to students?
}

\author{
Andreja Istenic ${ }^{1,2}$ \\ Published online: 9 March 2021 \\ (c) Association for Educational Communications and Technology 2021
}

\begin{abstract}
While online learning resources are proliferating in all education delivery modes, from traditional classes to distance learning, institutions may have not recognized their potential for addressing diverse student populations, providing them online with learning experiences according to their individual needs. If teachers embrace online learning and customize their approaches to make online resources accessible to students, the interactive and collaborative nature of online learning may help reduce the lack of interaction in large classes and isolation in distance education. Research reports the need to examine the accessibility of online learning through the lenses of the digital divide dependence on factors related to physical access, skills and motivational factors. The circumstances of the pandemic have revealed inequality in access to education caused by access to technology and online delivery in which teaching approaches may not necessarily address the student voice with appreciation of their culture. Discussion address Kuo and Belland (Educ Technol Res Dev 64:661-680, 2016) article which reports experiences of minority students (e. g., AfricanAmerican) in continuing education indicating that there has been little study of minority students' use of online learning resources. Authentic learning is highlighted by critical pedagogy as a means of engaging students in real-life problems and giving meaning to their real-life contexts as sources of learning and among which digital spaces play a prominent role in students' meaning-making.
\end{abstract}

Keywords Covid $19 \cdot$ Critical pedagogy $\cdot$ Online learning $\cdot$ Digital divide $\cdot$ Authentic learning $\cdot$ Internet self-efficacy $\cdot$ Minority students $\cdot$ Higher education $\cdot$ Adult education

While online learning resources are proliferating in all education delivery modes, from traditional classes to distance learning, institutions may have not recognized their potential for addressing diverse student populations, providing them online with learning experiences according to their individual needs. If teachers embrace online learning and customize their approaches to make online resources accessible to students, the interactive and collaborative nature of online learning may help reduce the lack of interaction in large

Andreja Istenič

andreja.istenic7@gmail.com

1 Faculty of Education, University of Primorska, Cankarjeva 5, 6000 Koper, Slovenia

2 Faculty of Civil and Geodetic Engineering, University of Ljubljana, Ljubljana, Slovenia 
classes and isolation in distance education. Research reports the need to examine the accessibility of online learning through the lenses of the digital divide (Lebeničnik and Istenič Starčič 2020), dependence on factors related to physical access, skills and motivational factors (Van Dijk 2017). Kuo and Belland (2016) report experiences of minority students (e. g., African-American) in continuing education indicating that there has been little study of minority students' use of online learning resources. The authors point to accessibility differences, referring to motivational factors influencing engagement and achievement of adult learners in online learning. Examining interaction patterns and their alignment with characteristics of specific minority student groups in online learning, they focus on students' self-efficacy, satisfaction and performance.

In this special issue, we revisit their article because the circumstances of the pandemic have revealed inequality in access to education caused by access to technology and online delivery in which teaching approaches may not necessarily address the student voice with appreciation of their culture. According to J. Dewey, students' experience in real-life contexts gives a meaningful framework for learning as shared experience and joint action related to the democratizing potential of education (1938/1997; 1973/1981). Giroux (2018) argued for pedagogy that is empowering and transformative, giving students their voice and recognize their cultural identity. Freire's (2008) concept of emancipatory pedagogy as a vehicle in adult education reveals complexity which needs to be addressed by educational technologists and educators.

Authentic learning is highlighted by critical pedagogy as a means of engaging students in real-life problems and giving meaning to their real-life contexts as sources of learning (Giroux 1988) and among which digital spaces play a prominent role in students' meaningmaking (Buckingham 1996; Kress 2003). As Giroux (2010) states, reflecting on Freire's work, pedagogy cannot be reduced to methods. Instead, it is a practice facilitating knowledge and social relations, seeking students as informed subjects for their engagement and participation.

Authentic learning consists of learner-side dimensions relying on learners' authenticity, together with those providing authenticity from the side of learning context and tasks. It draws from cognitive perspective of individual's cognition and capability in learning, which, from a socio-cultural perspective, is situated in a cultural context that requires learning that is dialogic and embodied in authentic cultural contexts. Learning design is a nexus point and meets the authenticity as culturally defined and determined by policy, system and curriculum when addressing: (1) the learner and (2) learning contexts (with objectives, contents and tasks). The affordance of digital learning technologies for authentic learning is threefold: it supports learning connected with real-life settings, real-life tasks and with the learner and her/his culture. Digital learning technologies connect real-life settings and pedagogical processes, both by providing authentic learning (simulations, virtual reality) in the school context, and establishing learning environments within authentic real-life settings (mobile technology). (Istenič Starčič 2020). Digital technologies have also been examined as an authentic cultural artefact (Vygotsky 1978) proliferating and changing cultural practices in all societal areas of life.

In response to Kuo and Belland (2016), Beth Beschorner and Benjamin Gleason address affordances of digital technologies for interactions in teaching process that facilitate student-centered learning, addressing minority adult learners' cultural background. Beschorner discusses the role of interaction facilitating equity in education, providing a response from the practice, cultural and inclusion aspect. She provides practical considerations for online teaching interactive practices. Gleason responds from the perspective of critical pedagogy. He discusses students' barriers to success and the role of interaction for 
critical thinking in an engaged active role in a community. He examines the role of pedagogical interaction and especially how it connects to the learner's world to social reality.

Equity in education must be addressed concerning all aspects of the courses. Adult education and distance learning have been regarded as a second chance. The digitalization of learning in the twentieth and twenty-first centuries requires a re-examination of adult and distance learning due to the increased availability of learning resources for interactive authentic learning in all educational contexts. Therefore, in the rapid shift to online, learning design could capitalize on this potential when designing inclusive learning environments for emergent requirements. The so called "usage gap" in online resources marked by gender, educational level and age has profound impact on social inequality indicating lower educated individuals not utilizing advanced applications in all spheres of life and especially in education and career (Van Dijk 2017). Usage gap can be addressed by learning design crossing boundaries between academic, personal lifestyle and professional sphere eliciting for authentic learning (Istenič Starčič et al. 2018). Digital practices saturating student's lifeworld need to be scrutinized when designing students' learning experience in search for authentic social practices.

\section{References}

Buckingham, D. (1996). Critical pedagogy and media education: A theory in search of a practice. Journal of Curriculum Studies, 28(6), 627-650. https://doi.org/10.1080/0022027980280601.

Dewey, J. (1938/1997). Experience and education. The Kappa Delta Pi Lecture Series. New York: A Touchstone book Simon \& Schuster.

Dewey, J. (1973/1981). The philosophy of John Dewey (Vols. 1-2, Ed. J. J. McDermott). Chicago: University of Chicago Press.

Freire, P. (2008). Teachers As Cultural Workers: Letters To Those Who Dare Teach. New York: Routledge.

Giroux, H. A. (1988). Teachers as Intellectuals: Towards a Critical Pedagogy of Learning. Granby, MA: Bergin \& Garvey.

Giroux, H. A. (2010). Rethinking Education as the Practice of Freedom: Paulo Freire and the promise of critical pedagogy. Policy Futures in Education 8(6), 715-721. https://doi.org/10.2304/pfie.2010.8.6.715

Giroux, H. A. (2018). Pedagogy and the Politics of Hope: Theory, Culture, and Schooling, A Critical Reader. New York, London: Routledge.

Istenič Starčič, A. (2020). Educational technology and construction of authentic learning environments Izobraževalna tehnologija in izgradnja avtentičnega učnega okolja. Ljubljana, Koper: UL FGG in UP. Retrieved from https://repozitorij.uni-lj.si/Dokument.php?id=136193\&lang=slv

Istenič Starčič, A., Terlevic, M., Lin, L., \& Lebeničnik, M. (2018). Designing learning for sustainable development: Digital practices as boundary crossers and predictors of sustainable lifestyles. Sustainability, 10, 20-30. https://doi.org/10.3390/su10062030.

Kuo, Y., \& Belland, B. R. (2016). An exploratory study of adult learners' perceptions of online learning: Minority students in continuing education. Educational Technology Research and Development, 64, 661-680. https://doi.org/10.1007/s11423-016-9442-9.

Kress, G. (2003). Literacy in the New Media Age. London: Routledge.

Lebeničnik, M., \& Istenič Starčič, A. (2020). Examining the contemporary digital divide of university students with specific reference to students with special educational needs. British Journal of Educational Technology, 51(6), 2422-2441. https://doi.org/10.1111/bjet.12920.

Van Dijk, J. A. G. M. (2017). Digital divide: Impact of access. In P. Rössler, C. A. Hoffner, \& L. van Zoonen (Eds.), International encyclopaedia of media effects (pp. 1-11). New York, NY: John Wiley \& Sons Inc.

Vygotsky, L. S. (1978). Mind in society The Development of Higher Psychological Process. Cambridge, Massachusetts, London: Harvard University Press.

Publisher's Note Springer Nature remains neutral with regard to jurisdictional claims in published maps and institutional affiliations. 
Andreja Istenič is author of the book Educational Technology and the Construction of an Authentic Learning Environment (2020). As a teacher educator with 20 years of experiences examines educational technology, teacher education, research evaluation in social science and humanities and professional learning in engineering education. She has a particular interest and involvement in interdisciplinary and cross-cultural research. Andreja was a visiting professor at Macquarie University Sydney (2012-13) and the University of North Texas Department of Educational Technology teaching PhD course Distributed learning environments (2018). Currently, she is a visiting professor at the Federal University Kazan. She was an editor for Europe of British Journal of Educational Technology and a member of the editorial board of Educational Technology Research and Development. She is a member of boards and contributes to educational and educational technology journals. Currently, she is examining play and early learning in the post-digital era and authentic learning environments constructed in societal processes utilizing physical and digital materiality. 